\title{
Analysis of the Relevance of Basic Electricity to Home Economics Students in Technical Colleges in Edo State, Nigeria
}

\author{
Sunday Oghor Osuyi ${ }^{1}$, Priscillia Anwuli Eboh ${ }^{2}$ \\ ${ }^{1,2}$ Department of Vocational and Technical Education, Faculty of Education, University of Benin, \\ Benin City, Nigeria. \\ Osuyideborah@gmail.com ${ }^{1}$
}

DOI: https://doi.org/10.37134/ajatel.vol10.2.4.2020

Received: 5 May 2020; Accepted: 07 July 2020; Published: 20 July 2020

Cite this article (APA): Osuyi, S. O., \& Eboh, P. A. (2020). Analysis of the relevance of basic electricity to Home Economics Students in Technical Colleges in Edo State, Nigeria. Asian Journal of Assessment in Teaching and Learning, 10(2), 27-33. https://doi.org/10.37134/ajatel.vol10.2.4.2020

\begin{abstract}
The study was designed to determine the relevance of basic electricity to home economics students in technical colleges in Edo state, Nigeria. In order to achieve the purpose of this study, three research questions were raised while one hypothesis was formulated. The study adopted the descriptive survey research design. The population and sample of the study consists of one hundred and forty (140) NTC II and III Home Economics students in four technical colleges in Edo State. A four point rating scale questionnaire titled Relevance of Basic Electricity to Home Economics Students Questionnaire (RBEHSQ)was the instrument used to collect data from the respondents. The face and content validity of the instrument was ascertained by two lecturers in department of vocational and technical education, and one Lecturer in department of measurement and evaluation, faculty of education, University of Benin, Benin city, Nigeria. The split half technique was used to determine the reliability of the instrument. The two sets of scores obtained were correlated using Pearson Product Moment Corrolation Coefficient (PPMCC) and the process yielded a correlation coefficient of 0.71 which means that the instrument was reliable. Mean $(\bar{X})$ and standard deviation (SD) were used to answer research questions 2 and 3 while research question 1 was answered with simple percentage. The hypothesis was tested at 0.05 level of significance with chisquare. Findings revealed that Home economics students are much aware of the relevance of basic electricity to home economics, students are moderately familiar with the basic electricity aspect of home economics programme and that the extent to which students are acquainted with basic electricity skills relevant to home economics is low. Tested hypothesis revealed that there is no significant difference between the perception of male and female students of the relevance of basic electricity to home economics. Based on the findings, it was recommended that efforts should be made by home economic lecturers to relate basic electricity to home economics so as to enable students become aware of the relationship between subjects, educational planners and school management should make adequate provision for necessary facilities for the teaching of basic electricity. School management should also ensure that only qualified lecturers are employed to teach home economics and that lecturers on their part should handle the basic electricity with all seriousness in such a way that would increase students' interest and acquire skills in basic electricity.
\end{abstract}

Keywords: Basic Electricity, Home Economics Students, Technical Colleges

\section{INTRODUCTION}

Electricity is one of the most important benefits of science to mankind. It has also become a part of modern life such that it has become almost impossible to do without it. The uses of electricity in the daily activities of man are enormous and it ranges from provision of illumination, working fans to powering domestic appliances including electric stoves, air conditioners amongst others with the aim of providing comfort for people. According to Akinoso (2011), in factories, large machines are worked with the help of electricity for the production of essential food items, cloth, papers and other products. Indeed, electricity has made the activities in all sectors easier. 
Similarly, in modern times, means of transportation and communication have been revolutionised by electricity. In the words of Usman and Nwoye (2010), electric trains and battery cars are quick means of transportation. Electricity also provides means of amusement through the use of radio, television and cinema, which are the most popular forms of entertainment. Modern equipment like computers and robots have also been developed with electricity. Electricity plays a pivotal role in the fields of medicines and surgery such as X-ray, Electrocardiogram. The use of electricity is increasing day by day.

Basic electricity therefore is a subject that is concerned with physical phenomena associated with the flow of electric charge. According to Taale and Mustapha (2014), Basic electricity helps students to understand the mechanism behind the various effects of electricity such as lightning, static electricity, electromagnetic induction and electrical current. In addition, electricity permits the creation and reception of electromagnetic radiation such as radio waves. The major objective of Basic electricity is to enable students acquire electrical skills and become proficient in elementary electricity. In the words of Taale and Mustapha, Basic electricity is directed at providing students with electrical skills that will, in the first place, help them to become self-employed, sustained and consequently earns a living from their business activities. Secondly, the knowledge and skill of basic electricity will help students to provide solutions to minor electrical problems in their environments instead of employing or inviting an external body to do the job.

According to National Business and Technical Examinations Board NABTEB (2019), the focus of Basic electricity include structure of matter, conductors and insulators, ohm's law and its application, resistors, capacitors and inductors, values and functions of resistors, electromotive force (e.m.f.), aside current \& direct current, electrical circuits, indicating instruments and measuring instruments, magnetism, induction and transformers, fluxes, solders and soldering, electronic signs and symbols, wiring and connection of electrical/electronic component.

In school setting, lack of electricity can be very frustrating because it is of multiple services in the classroom, laboratories, and workshops. Proper illumination can enhance and make early morning or late night classes more possible, comfortable and enjoyable. It facilitates the use of ICTs in the classroom such as computers and televisions. According to Ada, Omalle \& Okedi (2014), the presence of electricity in the school creates a relaxed and cool environment which is learners friendly. In other words, electricity enhances teaching and learning of all subjects. For practical based subjects like Home Economics, the availability of electricity is very pertinent because of electrically powered equipment used in home economics laboratories. Therefore, lack of electricity could hinder the acquisition of practical knowledge in home economics and other related subjects.

Home economics, according Nwakwo (2011), is a broad field of study which brings together knowledge from many discipline for the purpose of achieving and maintaining the well-being of an individual and families in an ever changing society. Nwachukwu (2010) described home economics as a human resource development for self-reliance by teaching individual how to raise money and their standard of living through various tasks and skills in home economics programmes such as clothing construction, textile science, catering services, basic agriculture, home management and child development or child upbringing. Nwachukwu further describe home economics as a science based subject having its knowledge and principles deeply rooted in all sciences, be it natural or biological, physical or social. It equips students with scientific and educational skills that helps in solving societal problems. Nigerians in general have at various times, involved in one form of poverty alleviation programme or the other but have not been able to actually move out of poverty. One of the ways that this could be possible is through home economics. In line with this assertion, Olaitan (2016) opined that home economics is cardinal to the development of human/capital resources. This is justifiable in view of the fact that Home Economics Education, poverty and human development were all people's issues and centered on people.

Audu and Abdulkadir, (2015) asserted that Home Economics Education prepares students for the acquisition and development of skills and competencies, attitude and attributes which are necessary for efficiency of the economic system. It is that aspect of the total education programme that provides the knowledge, skills, understanding and attitude needed to perform in the business world as a producer or consumer of goods and services that business offers and also makes people to be job producers rather than job seekers. In order to make this assertion a reality, the home economics students must be trained 
to acquire both cognitive knowledge and skills in fashion design, food and nutrition, baking, decoration and indeed home management.

In modern days, the tools and equipment used to carry out the aforementioned are electric power driven. Examples are power driven sewing machines, electric pressing iron, flour mixer, oven, blender among others. These equipment are connected to electric power sources with either a two-pin plug or a three pin plug. The circuit breakers which are usually connected to the switches of these equipment are incorporated with fuses. In the process of using these equipment, the fuse could get burnt and this usually lead to stoppage of work. It is therefore expected of home economics students to have knowledge and skills that would enable them to replace burnt fuse, or bad cable in any of the equipment that develops such fault. The time wasted and the money that would be spent to employ a technician to fix the damaged parts could be saved. It is on this note that the syllabus of home economics and related subjects at technical colleges are designed such that basic electricity is a core subject.

\section{STATEMENT OF THE PROBLEM}

As a skill oriented course, home economics possesses the capability of equipping individuals with sellable skills that make for self-employment, self-reliance and creation of wealth. It is an all embracing programme that focuses on the welfare of individuals and their families. It is a vocational and skill based education which prepares one for gainful employment, employer of labour, good family living, self employment and development of the society. It equips individuals to attain and live a useful and satisfying life.

These are made possible if home economics students are trained with laboratory equipment that are electric power driven. Examples are electric oven, electric yam pounder, electric blender, electric sewing machines, electric pressing iron, electric stove and many equipment. In the process of training college students with these equipment, they are expected to acquire skills needed to carry out minor maintenance and repair of these equipment by offering basic electricity.

Despite the importance of basic electricity to home economic education programme, technical college students seem not to be aware of its relevance to their studies. This fact is demonstrated by the attitude of home economics students towards basic electricity. The authors observed that most home economics students who registered for basic electricity in National Technical Certificate Examination (NTCE) do not write the examination, probably because they are not prepared and do not know why they need the knowledge and skill. The worry is that if this trend continues, home economics students who are graduating from technical colleges in Nigeria might not be able to use home economics appliances effectively. This could hinder self-empowerment and wealth creation and indeed bring about unemployment and poverty in Nigeria. To this end, this paper seeks to examine the relevance of basic electricity to home economics students in technical colleges, in Nigeria.

\section{Purpose of the Study}

The main purpose of this study was to ascertain the relevance of basic electricity to home economics students, specifically, the study determined

1. students' level of awareness of the relevance of basic electricity to home economics;

2. the extent to which students are familiar with basic electricity aspect of home economics programme;

3. the extent to which students are acquainted with basic electricity skills relevant to home economics.

\section{Research Questions}

The following research questions were raised to guide the study.

1. What is the level of students' awareness of the relevance of basic electricity to home 
economics?

2. To what extent are students familiar with basic electricity aspect of home economics programme?

3. To what extent are students acquainted with basic electricity skills relevant to home economics?

\section{Hypothesis}

There is no significant difference between the perception of male and female students of the relevance of basic electricity to home economics.

\section{METHODOLOGY}

The study adopted the descriptive survey research design. The population of the study consisted of one hundred and forty (140) NTC II and III Home Economics students in four technical colleges in Edo State, namely Afuze Technical College, Afuze, Igara Technical College, Igarra, Benin Technical College, Federal Science Technical College, Uromi. The population was used as the sample size because it was manageable. A four point rating scale questionnaire titled Relevance of Basic Electricity to Home Economics Students Questionnaire (RBEHSQ) was the instrument used to collect data from the respondents. The face and content validity of the instrument was ascertained by two experts in department of vocational and technical education, faculty of education, University of Benin, Benin City, Nigeria and one expert in department of measurement and evaluation, faculty of education, University of Benin, Benin City, Nigeria. The split half technique was used to determine the reliability of the instrument. The two sets of scores obtained were correlated using Pearson Product Moment Corrolation Coefficient (PPMCC) and it yielded a correlation coefficient of 0.71 which means that the instrument was reliable. Mean $(\bar{X})$ and standard deviation (SD) were used to answer research questions 2 and 3 while research question 1 was answered with simple percentage. The hypothesis was tested at 0.05 level of significance with chi-square as the test is Non-parametric (Ramnath, 2018). For research question 1, if the calculated percentage is equal or greater than 50, it was regarded as much aware (MA), whereas less than 50 was considered less aware (LA). It is agreed for research questions 2 and 3 if the mean value is equals or greater than 2.50 , otherwise it was considered as disagreed. Decision for the acceptance or rejection of the hypothesis was based on the P-value.

\section{RESULTS}

Research Question 1: What is the level of students' awareness of the relevance of basic electricity to home economics?

Table 1. Distribution of responses on level of students' awareness of the relevance of basic electricity to home economics

\begin{tabular}{|c|c|c|c|}
\hline Level of Response & Frequency & Percentage & Decision \\
\hline Much Aware & 85 & 60.7 & Much Aware \\
\hline Less Aware & 55 & 39.3 & \\
\hline Total & 140 & 100 & \\
\hline
\end{tabular}

Table 1 shows that $60.7 \%$ of the sampled respondents indicated that they are much aware of the relevance of basic electricity to home economics, while $39.3 \%$ of them responded that they are less aware of the relevance of basic electricity to home economics. This means that greater percentage of the students is much aware of the relevance of basic electricity to home economics.

Research Question 2: To what extent are students familiar with basic electricity aspect of home economics programme? 
On the issue of the extent to which students are familiar with basic electricity aspect of home economics programme, data in Table 2 shows that items 1 and 3 showed the mean score of 2.50 and thus were high extent while items 2 and 4 were low extent of the level of students' familiarity with basic electricity aspect of home economics.

Table 2. Distribution of responses on the extent to which students are familiar with basic electricity aspect of home economics programme

\begin{tabular}{|l|c|c|c|c|}
\hline \multicolumn{1}{|c|}{ Item Statement } & N & Mean & $\begin{array}{c}\text { Standard } \\
\text { Deviation }\end{array}$ & Decision \\
\hline $\begin{array}{l}\text { To what extent are home economics students familiar } \\
\text { with simple maintenance and repair of electric sewing } \\
\text { machine? }\end{array}$ & 140 & 2.51 & 1.1 & High Extent \\
\hline $\begin{array}{l}\text { To what extent are home economics students familiar } \\
\text { with simple maintenance and repair of laundry } \\
\text { equipment? }\end{array}$ & 140 & 2.39 & 1.1 & Low Extent \\
\hline $\begin{array}{l}\text { To what extent are home economics students familiar } \\
\text { with simple maintenance and repair of electric } \\
\text { cooking utensils? }\end{array}$ & 140 & 2.60 & 1.0 & High Extent \\
$\begin{array}{l}\text { To what extent are home economics students familiar } \\
\text { with simple maintenance of home economics } \\
\text { laboratory? }\end{array}$ & 140 & 2.28 & 1.0 & Low Extent \\
\hline
\end{tabular}

Research Question 3: To what extent are students acquainted with basic electricity skills relevant to home economics?

Table 3. Distribution of responses on the extent to which students are acquainted with basic electricity skills relevant to home economics

\begin{tabular}{|l|c|c|c|c|}
\hline \multicolumn{1}{|c|}{ Item Statement } & N & Mean & $\begin{array}{l}\text { Standard } \\
\text { Deviation }\end{array}$ & Decision \\
\hline $\begin{array}{l}\text { To what extent are home economics students } \\
\text { acquainted with skills in basic electricity to be able to } \\
\text { maintain home economics electrical appliances? }\end{array}$ & 140 & 2.44 & 1.0 & Low extent \\
\hline $\begin{array}{l}\text { To what extent are home economics students } \\
\text { acquainted with skills to enable them use an electric } \\
\text { sewing machine? }\end{array}$ & 140 & 2.35 & 1.1 & Low extent \\
\hline $\begin{array}{l}\text { To what extent are home economics students } \\
\text { acquainted with electrical skills needed to detect } \\
\text { electrical problems in workshops? }\end{array}$ & 140 & 2.39 & 1.1 & Low extent \\
\hline
\end{tabular}

Data in Table 3 shows that all the items did not meet the mean score of 2.50 . It means that the extent to which home economics students are acquainted with basic electricity skills relevant to home economics is low.

\section{Hypothesis Test}

Ho: There is no significant difference between the perception of male and female students of the relevance of basic electricity to home economics.

Table 4. Responses on the perception of male and female students of the relevance of basic electricity to home economics

\begin{tabular}{|l|c|c|c|c|}
\hline \multicolumn{5}{|c|}{ Chi-Square Tests For Gender Difference } \\
\hline & Cal Value & df & P-value & Decision \\
\hline Pearson Chi-Square & $3.225^{\mathrm{a}}$ & 1. & .073 & Retained \\
\hline Continuity Correction $^{\mathrm{b}}$ & 2.398 & 1. & .122 & \\
\hline
\end{tabular}




\begin{tabular}{|l|l|l|l|l|}
\hline Likelihood Ratio & 3.266 & 1. & .071 & \\
\hline
\end{tabular}

$\mathrm{P}$ Value $>0.05$

Calculated value $=3.22$

Table value $=3.84$

Data in Table 4 reveals that calculated value of 3.22 at 1 degree of freedom and 0.05 level of significance is less than Table value of 3.84 hence the null hypothesis is retained. This therefore means that there is no significant difference between the perception of male and female students of the relevance of basic electricity to home economics students.

\section{DISCUSSION OF FINDINGS}

Findings from the study have been quite revealing. Answers to the research questions showed that students are much aware of the relevance of basic electricity to home economics. This is no doubt traceable to students' knowledge of basic electricity as it concerns home economics. Hence Audu and Abdulkadir, (2015), who reported that the home economics students have an appreciable level of knowledge of basic electricity hence the need to intensify effort in teaching it to the students.

Secondly, findings also revealed that students are moderately familiar with the basic electricity aspect of home economics programme. Since the students have little or no familiarity with the basic electricity aspect of home economics programme, it is very much likely that their interest in basic electricity will be affected and this will in turn affect the application of the knowledge and skills of basic electricity in home economics. This statement is corroborated by the next finding from the study which reveals that the extent to which students are acquainted with basic electricity skills relevant to home economics is low. Buttressing these findings, Akinoso (2011) opined that when students are aware of the relevance of a subject in relation to their future carriers, it increases their interest and helps to energize them toward high achievement in the subject. Similarly, Adebayo (2017) posited that there is a significant relationship between interest and academic achievement and daily application of the knowledge gained from such subject. Kabir (2013) also indicated that ability for learners to develop and sustain interest in a subject goes a long way to determine how much they can achieve from such subject.

Finally, findings from hypotheses test shows that there is no significant difference between the perception of male and female students of the relevance of basic electricity to home economics. This finding is corroborated by that of Ogedengbe (2014) who reported that students were united in their perception of their relevance of basic electricity to home economics.

\section{CONCLUSION AND RECOMMENDATIONS}

This study has shown that advancing the knowledge of basic electricity in home economics education is necessary for students to eliminate abject poverty in the society, also become able to properly manage equipment and appliances used in home economics. Though obvious factors tend to limit or pose as challenge to the effective teaching and learning of basic electricity, it is yet known that with interest and commitment, students can acquire whatever skill they desire. In the light of this therefore, this paper offers the following recommendations:

1. The study and practice of basic electricity in Home Economics should be emphasized by educational planners.

2. Efforts should be made by home economic lecturers to relate basic electricity to home economics so as to enable students become aware of the relationship between both subjects.

3. Educational planners and school management should make adequate provision for necessary facilities for the teaching of basic electricity. School management should also ensure that only qualified lecturers are employed to teach home economics. 
4. Lecturers on their part should handle the basic electricity with all seriousness in such a way that would increase students' interest and acquire skills in basic electricity. They should also help home economics students to see the relevance and benefits of the course in their daily activities.

\section{REFERENCES}

Ada, O. C. Omalle, M. C. \& Okedi, P. A. (2014). Privatization of vocational and technical education for the attainment of national educational goals. Journal of Vocational and Technical Educators 1 (1) 22-28.

Adebayo, T. O. (2017). Business Education: A Panacea for Poverty Amelioration. Book of Reading 1:7-33.

Akinoso, S.O. (2011). Correlates of some factors affecting students' achievement in secondary school Mathematics in Osun State. International Journal of Education, Science, Mathematics and Environmental Studies (1 JESMES), University of Abuja 3(1), 83-95.

Audu, R. \& Abdulkadir, R. (2015). Eradication of child labour through home economics education. JOWICE 13 (2), 95-99.

Kabir, S.O. (2013). The role of vocational technical education in community development. Nigerian Journal of Curriculum and Instruction 2 (2), 109-112.

Nwachukwu, C. E. (2010). Designing appropriate methodology in vocational and technical education for Nigeria. Nsuka: Fulladu Publishing Company.

Nwakwo, J.N. (2011). An introduction to home economics education. Ughelli: Eddy-Joe Publishers.

Olaitan, S.O. (2016). Vocational and Technical Education in Nigeria: Issues and Analysis. Onitsha: Noble graphic Press.

Ramnath, T. (2018). Suitability of Chi-square in probability and statistical testing. Retrieved July $1^{\text {st }} 2020$ from https://www.researchgate.net/post/justification_of_Chi_Square_as_a_Non-Parametric_Test

Taale, K. D. \& Mustapha B. A. (2014). Effects of teacher-constructed electrical models on students' academic achievement in basic electricity in technical colleges of Borno state, Nigeria. International Journal of Innovative Social \& Science Education Research 2 (1) 16-25

Usman, K.O. and Nwoye, M. N. (2010). Effect of graphical symbol approach on the pupils' achievement in ratio at upper Primary school level in Nsukka central L.G.A. Journal of Mathematical Sciences education 1 (1), $123-132$. 